African Crop Science Journal by African Crop Science Society is licensed under a Creative Commons Attribution 3.0 Uganda License. Based on a work at www.ajol.info/ and www.bioline.org.br/cs DOI: https://dx.doi.org/10.4314/acsj.v29i4.7

\title{
WEATHER VARIABILITY IN DERIVED SAVANNAH AND RAINFOREST AGROECOLOGIES IN NIGERIA: IMPLICATIONS FOR CROP YIELDS AND FOOD SECURITY
}

\author{
O.I. AKANO, K.O. OLUWASEMIRE², M.S. MODIRWA, O.O. AMINU ${ }^{3}$, F.O. ODERINDE ${ }^{4}$ \\ and O.I. OLADELE
}

Department of Agricultural Economics and Extension, North-West University, South Africa

${ }^{1}$ Sasakawa Africa Fund for Extension Education (SAFE) Ethiopia/Nigeria

${ }^{2}$ Department of Soil Resources Management, University of Ibadan, Ibadan, Nigeria

${ }^{3}$ Department of Agricultural Extension and Rural Development, University of Ibadan, Ibadan, Nigeria

${ }^{4}$ Department of Geography and Environmental Management, Tai Solarin University of Education, Ijagun, Ogun State, Nigeria

Corresponding author: olalekanore@ymail.com

(Received 20 July 2021; accepted 21 December 2021)

\begin{abstract}
Weather variability and its effects on agricultural and food systems are burgeoning global concerns. This study examined the effects of weather variability in the derived savannah and rainforest agroecologies, on crop yields in Southwest Nigeria, and what it portends for food and nutrition security in the region. The trends in the distribution of rainfall and temperature were analysed using the Sens method. The effects of weather variability on crop yield and inferences on what it portends for food security were determined using a stepwise regression model. The results revealed that rainfall fluctuations decreased the yields of cassava (Manihot esculenta) and yam (Dioscorea spp.) in the derived savannah; while a decrease in temperature may support improved yields for maize (Zea mays), sorghum (Sorghum bicolor) and cowpea (Vigna unguiculata). The increase in yields of cocoa (Theobroma cacao) and cocoyam (Colocasia esculenta) would be hampered by increasing maximum temperatures in the rainforest agroecology. Increasing rainfall and temperature would impact warmer conditions that support rapid crop putrefaction, flooding, droughts, challenging postharvest crop management, pest and disease proliferation, and ultimately, reduced crop yields. On the other hand, perpetually low rainfall and temperature conditions will cause poor seedling emergence and growth, seed and total crop loss. It is, therefore, imperative that effective climate adaptation and mitigation mechanisms be put in place across the agroecologies in the region.
\end{abstract}

Key Words: Agroecology, food security, rainfall, temperature 


\section{RÉSUMÉ}

La variabilité météorologique et ses effets sur les systèmes agricoles et alimentaires sont des préoccupations mondiales en plein essor. Cette étude a examiné les effets de la variabilité météorologique dans les agroécologies dérivées de la savane et de la forêt tropicale humide sur les rendements des cultures dans le sud-ouest du Nigeria, et ce qu'elle présage pour la sécurité alimentaire et nutritionnelle dans la région. La tendance de la distribution des précipitations et de la température a été analysée à l'aide de la méthode Sens. Les effets de la variabilité météorologique sur le rendement des cultures et les déductions sur ce qu'elle présage pour la sécurité alimentaire ont été déterminés à l'aide d'un modèle de régression progressive. Les résultats ont révélé que les fluctuations des précipitations diminuaient les rendements du manioc (Manihot esculenta) et de l'igname (Dioscorea spp.) dans la savane dérivée ; tandis qu'une diminution de la température pourrait favoriser l'amélioration des rendements du maïs (Zea mays), du sorgho (Sorghum bicolor) et du niébé (Vigna unguiculata). L'augmentation des rendements du cacao (Theobroma cacao) et du cocoyam (Colocasia esculenta) serait entravée par l'augmentation des températures maximales dans l'agroécologie de la forêt tropicale. L'augmentation des précipitations et de la température aurait un impact sur des conditions plus chaudes qui favorisent la putréfaction rapide des cultures, les inondations, les sécheresses, la gestion des cultures post-récolte difficile, la prolifération des ravageurs et des maladies et, en fin de compte, la réduction des rendements des cultures. D'autre part, les précipitations et les conditions de température perpétuellement basses entraîneront une mauvaise émergence et croissance des semis, des semis et une perte totale de récolte. Il est donc impératif que des mécanismes efficaces d'adaptation et d'atténuation du climat soient mis en place dans les agroécologies de la région.

Mots Clés : Agroécologie, sécurité alimentaire, précipitations, temperature

\section{INTRODUCTION}

The unpredictable trends in weather variability will continue to adversely affect agricultural systems globally (Houghton, 2009). It is expected to increase farm abandonment, reduce water supplies, dwindle agricultural yields, foster poverty and cause food and nutrition insecurity, especially among rural dwellers and smallholder farmers whose livelihood sources are mainly dependent on agriculture (Solomon et al., 2007; AGRA, 2014). Smallholder farmers in sub-Saharan Africa (SSA) and their farming systems are at a greater risk of weather variability owing to their lack of capacity to adequately adapt to unending weather changes (Shah et al., 2008). In fact, research shows that only a minority of them takes advantage of the full adaptation options (Fosu-Mensah et al., 2012), thereby making them vulnerable to climate vagaries.

Due to their heavy reliance on rain-fed agriculture, SSA smallholders are more vulnerable since only approximately four percent of Africa's cultivated cropland is irrigated (Ifejika Speranza, 2010; IFAD, 2011; FAO, 2015). Approximately $90 \%$ of the SSA population depends on rain-fed agriculture for food production and weather variability may impact up to $20 \%$ reductions in crop yields by 2050 (FAO, 2006). This posits that most smallholder farmers plan agricultural production based on rainfall events, anticipating both expected and undesirable outcomes.

Nearly $65 \%$ of African countries have reported weather-related crises such as severe droughts (Em-dat, 2013). Inadequate rainfall, with its uneven distribution, and its exacerbation by weather variability is being experienced across countries like Nigeria (Bello et al., 2012; Ajetomobi et al., 2015). Extreme weather events are expected to be on the rise, especially in the form of droughts and floods that can destroy crops and farmers' livelihoods. A decline in precipitation, ranging from 20 to $40 \%$ between the periods of 1931 
and 1960, and 1968 and 1990, has been observed in West Africa ( Solomon et al., 2007; Sissoko et al., 2011). Fabusoro et al. (2014) reported that the trends of rainfall and temperature over Southwest Nigeria are increasing; while Ayanlade et al. (2017) reported a reduction in the trend of rainfall in the same region.

This study examined the effect of weather variability in the derived savannah and rainforest agroecologies on crop yields in Southwest Nigeria, and what it portends for food and nutrition security.

\section{MATERIALS AND METHODS}

Study area. This study was conducted in Oyo state in Southwest Nigeria. Oyo state comprises of two main agroecological zones, namely, the derived savannah and the rainforest (Fig. 1). The derived savannah comprises of woodland savannah covering local government areas including, Saki East, Saki West, Irepo, Iseyin, Oyo East, Oyo West, Ogbomosho North and Ogbomosho South. It supports the cultivation of crops such as maize, yam, cassava, cashew, soybean, pepper, mango and shea butter.
The rainforest agroecology is mainly found in the Ibadan area, covering local government areas including Oluyole, Akinyele, Ona-ara, Egbeda and Lagelu (Fig. 1). The agroecology also favours production of food crops such as cassava, yam, sweet potato and maize and tree crops such as cocoa, citrus and oil palm. The rainfall pattern in Oyo state is bimodal, running from March to October, and a dry season accompanied by the Northeast trade wind with Harmattan and dust from the Sahara Desert is experienced between November and February (Sangotegbe et al., 2015). The derived savannah agroecological zone receives an average rainfall of less than $1340 \mathrm{~mm}$; while the rainforest agroecology receives more than $1340 \mathrm{~mm}$ of rainfall annually (Oni et al., 2013).

Data sources. The weather dataset used for this study was limited to a time series of 27year period due to the inability to access 30 year data on crop yields from the relevant agencies at the time of data request, access and curation. This scenario resulted in the use of the term 'weather' instead of 'climate' as observed in this study because 'climate' may refer to a time series of meteorological data of 30 years or more (Solomon et al., 2007).
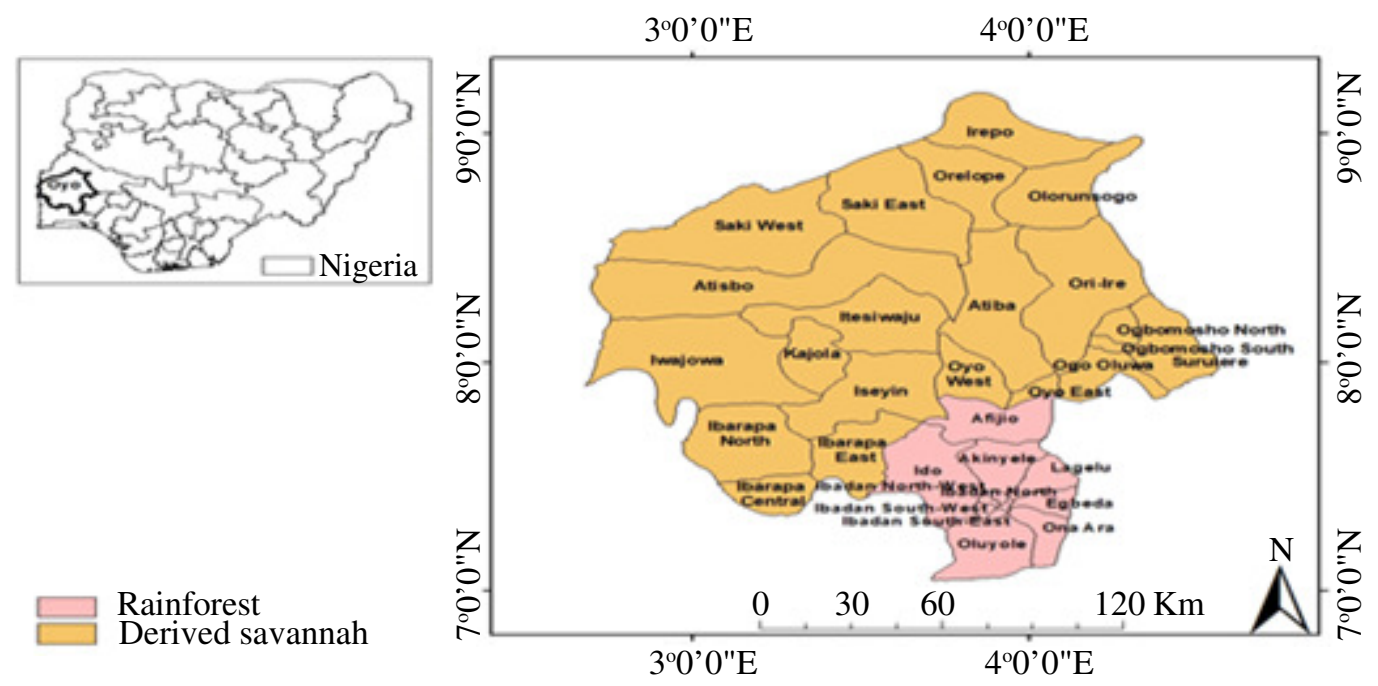

Figure 1. Agroecological zones of Oyo state. 
The data for arable crop yields were obtained from the Oyo State Agricultural Development Programme (OYSADEP); while those for tree crops were obtained from the State Ministry of Agriculture, Rural Development and Natural Resources. The historical weather data (1990 - 2016) in two agroecological zones, the rainforest (represented with data from International Institute of Tropical Agriculture weather station Ibadan) and derived savannah (represented with data from Nigerian Meteorological Agency weather station Saki) were tested for variability. This was done using the Sens method (Gilbert, 1987) and executed with MAKESENS 1.0 software.

\section{Description of the empirical model}

A stepwise regression model. A stepwise regression method was used to ascertain the most important weather variables influencing crop yields in Oyo state. This was done to draw inferences from the statistical procedures employed and to address the study objectives. The stepwise regression model can fine-tune and ascertain the order of importance of the independent variable (Lewis, 2007). Variables retained at the end of the model run are found to show high predictive values. Due to the timeframe limitation of the available data, time series models such as the Auto Regressive
Integrated Moving Average (ARIMA) and Vector Error Correlation Model (VECM), which require large observations were not considered.

Table 1 highlights the dependent and explanatory variables in the model. Crop yield values were converted to a $\log$ of base 10 to normalise skewed values and allow curve fitting before they were fitted into the model. As such, the coefficients are reported in percentages. A backward approach was employed where independent variables were loaded at once into the model and those that did not have influence on the dependent variable were determined through an Fstatistics test with probability significance levels $>10 \%$, hereafter removed from the model with the progression of the regression. The stepwise regression model is expressed as follows:

$Y=\beta 0+\beta 1 X 1+\beta 2 X 2+\beta 3 X 3+\beta 4 X 4+$

$\beta 5 X 5 \ldots . . \beta n X n+\varepsilon$

Where:

$Y=$ crop yield (metric tonnes per $1000 \mathrm{ha}$ ), $X$ $=$ independent variables, $\beta=$ coefficient of parameters, $\beta 0=$ intercept and $\varepsilon=$ error term. Backward elimination of the independent variable occurred after the F-statistic was calculated using the $P$ value.

TABLE 1. Description of dependent and independent variables used in the stepwise regression model

\begin{tabular}{ll}
\hline Variables & Measurement \\
\hline $\begin{array}{l}\text { Dependent } \\
\text { Crop yield }\end{array}$ & Tonnes per 1000 ha \\
Independent & \\
Rainfall & Yearly sum measured in mm \\
Maximum temperature & Yearly average measured in ${ }^{\circ} \mathrm{C}$ \\
Minimum temperature & Yearly average measured in ${ }^{\circ} \mathrm{C}$ \\
\hline
\end{tabular}


$F=\frac{\left(S S E_{j-x r}-\frac{S S E_{j}}{D F_{x r}}\right)}{M S E_{j}}$

$\mathrm{SSE}_{\mathrm{j}-\mathrm{xr})}=$ the sum of the square error for

the model without $\mathrm{xr} ; \mathrm{SSE}_{\mathrm{j}}=$ the sum of the square error for the model with; and = mean square for model with.

A percentage change in the mean square error is observed when the independent variables are removed. It is expressed as follows:

Percentage change $=$

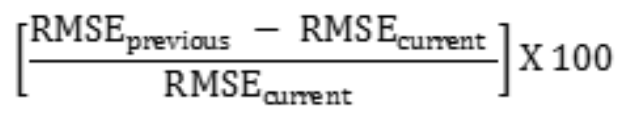

Where:

RMSE $=$ root mean square error

Sen's method for detecting monotonic trends in weather data. Sen's nonparametric test was used to estimate if there existed a linear trend in the weather variables across the agroecologies in the study area. It is expressed as:

$f(t)=Q t+B$

Where:

$f(t)$ is a function of time representing an increase or decrease and represents time in years. $Q$ is the slope of the equation, while is the constant (Salmi, 2002).

$Q$ can be further expressed as:

$$
\mathcal{Q}_{i}=\frac{x_{j}-x_{k}}{j-k}
$$

Where:

$j>k$, and $i=1,2,3 \ldots N$

At $n$ values of $x_{j}$ in the time series, we obtain as many as $N=n(n-1) / 2$ slope that estimates $Q_{\text {i }}$

The $N$ values of $Q_{\mathrm{i}}$ can be ranked from smallest to largest, where Sens's estimator, which is the median of $N$ values of $Q_{\mathrm{i}}$, is expressed as:

$Q=Q_{[(\mathrm{N}+1) / 2]}$, if $N$ is odd

$\mathcal{Q}=\frac{1}{2}\left(\mathcal{Q}_{[N / 2]+} \mathcal{Q}_{[(N+2) / 2]}\right)$ if $N$ is even ..(6)

Maps depicting the spatial outlook of the effects of weather variability across agroecologies on selected crop yields were generated by interpolation using ArcGIS (ArcMap) version 10.5. SAS version 9.1 was used for executing the stepwise regression.

\section{FINDINGS}

Rainfall distribution trends. Figures $2 \mathrm{a}$ and $3 \mathrm{a}$, respectively show that the lowest amount of rainfall experienced in the derived savannah was $840 \mathrm{~mm}$ in 2012 and $794.3 \mathrm{~mm}$ for the rainforest in 1998. However, the highest amount of rainfall recorded for the derived savannah was $1469.1 \mathrm{~mm}$ in 1995 and 1926.3 $\mathrm{mm}$ for the rainforest in 2010. This shows a deviation in the pattern, with the highest amount of rainfall recorded in earlier years for the derived savannah. No statistically significant trend was found in the distribution of rainfall in the derived savannah $(Z=-0.04)$ and rainforest $(Z=0.83)$, but reductions were observed in the derived savannah and an increasing pattern in the rainforest over the timeframe.

Maximum temperature trends. There was variation in the maximum temperature 
(a)

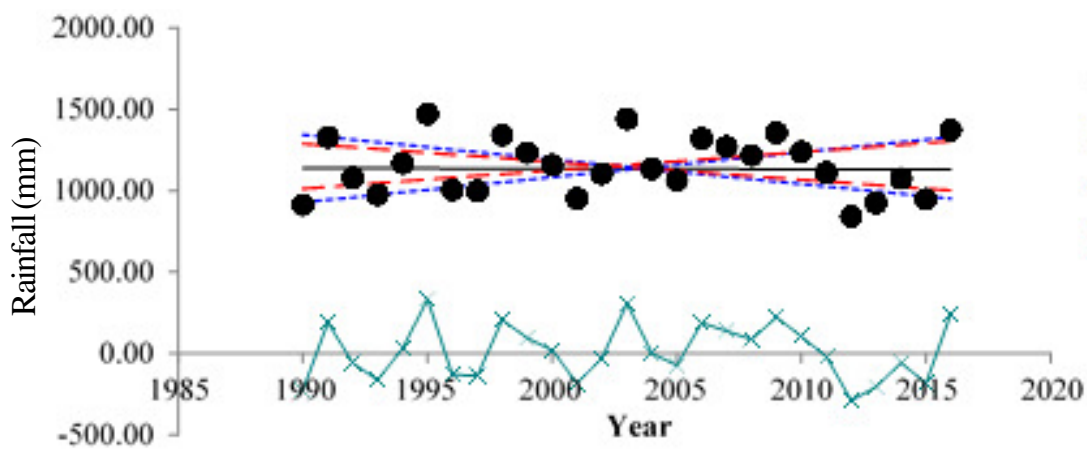

- Data Sen's estimate $99 \%$ conf. min $99 \%$ conf. max $---95 \%$ conf. $\min$ $---95 \%$ conf. max $\longrightarrow$ Residual

(b)
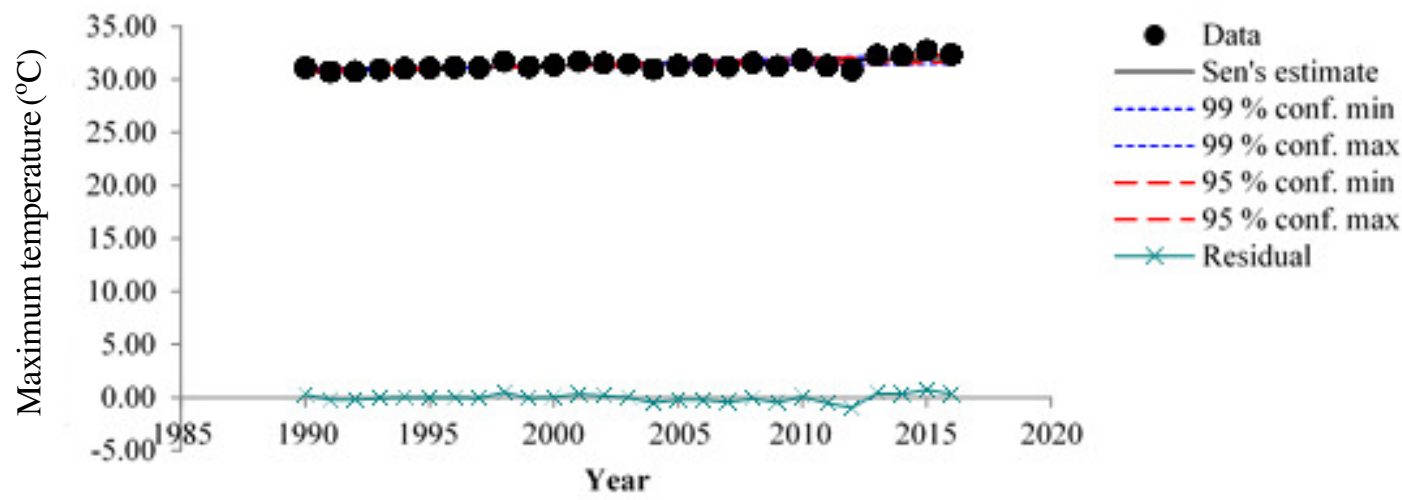

(c)
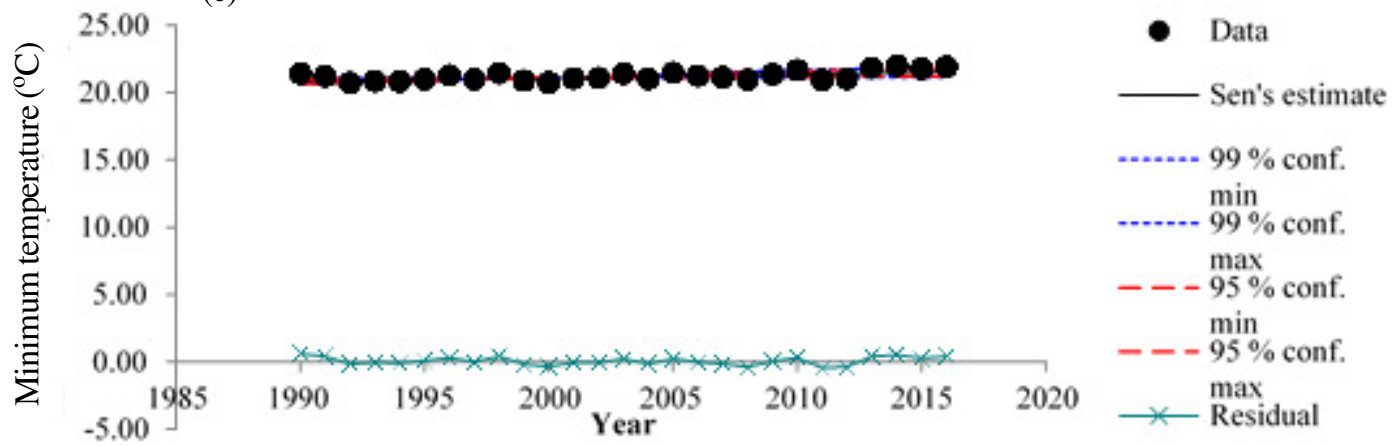

Figure 2. Weather variability and trend across the derived savannah agroecology of Oyo state: (a) rainfall (b) maximum temperature (c) minimum temperature. 
(a)
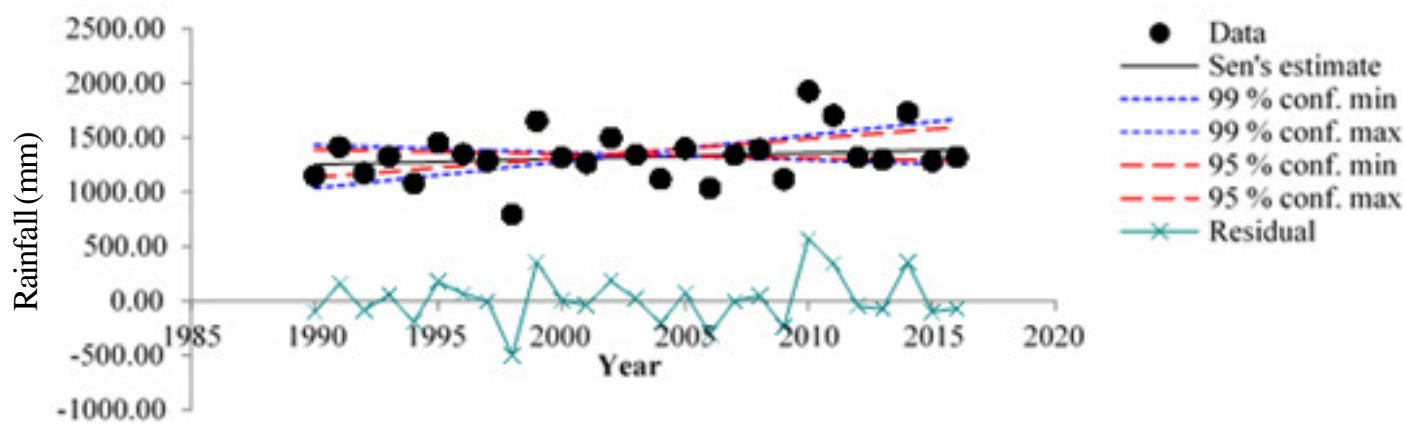

(b)
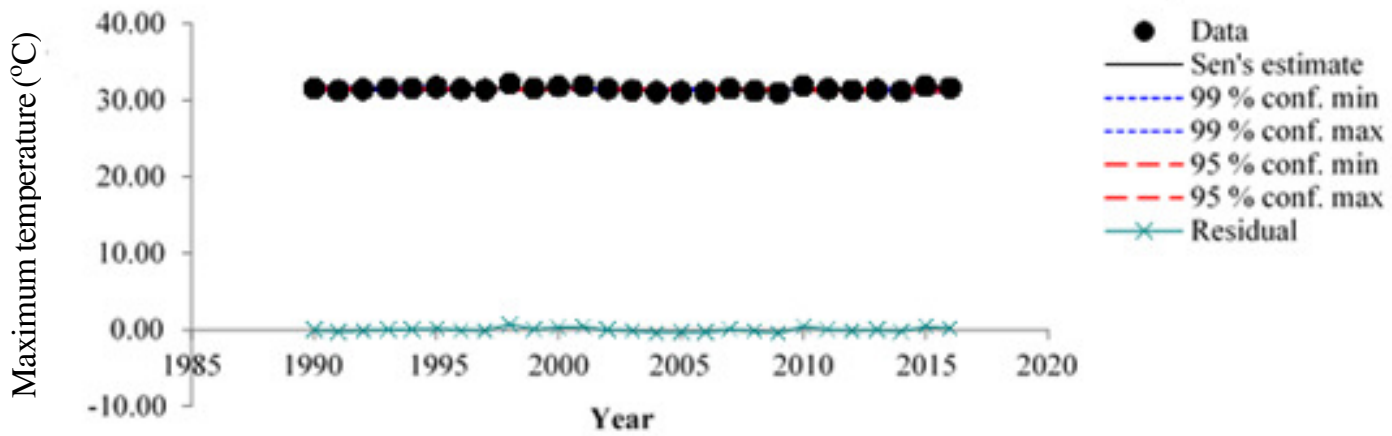

(c)

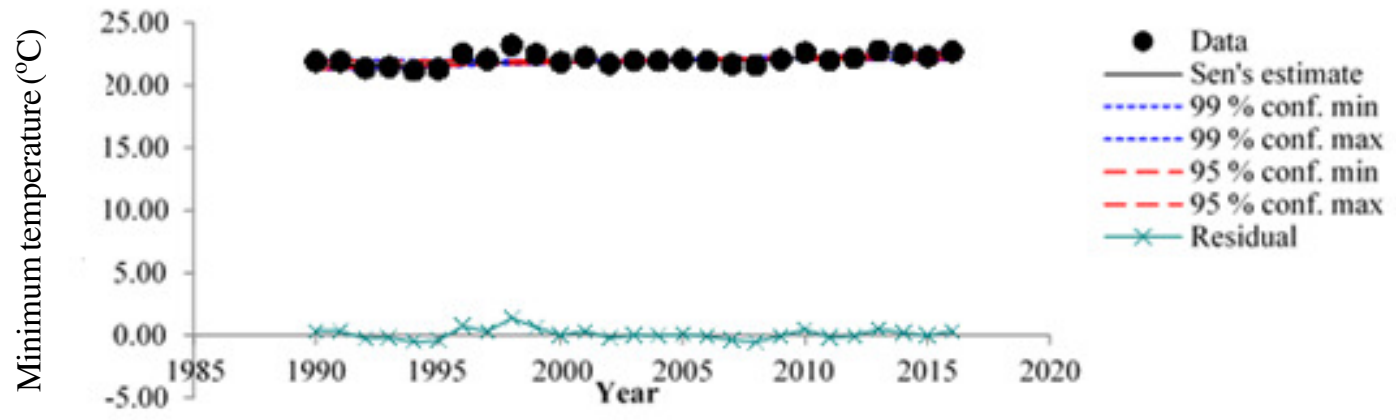

Figure 3. Weather variability across the rainforest agroecology of Oyo state: (a) rainfall (b) maximum temperature (c) minimum temperature. 
recorded in both agroecologies (Figs. 2b and $3 \mathrm{~b})$. The lowest maximum temperatures recorded were 30.4 and $30.3{ }^{\circ} \mathrm{C}$, both in 1986 , for the derived savannah and rainforest agroecologies, respectively. However, the highest maximum temperature observed was $32.7^{\circ} \mathrm{C}$ in 2015 for the derived savannah and $32.2^{\circ} \mathrm{C}$ in 1998 for the rainforest. Increasing and statistically significant trends were observed in the temperature values for the derived savannah $(\mathrm{Z}=3.88, \mathrm{P}<0.001)$, and decreasing values had no trends in the rainforest agroecology $(-0.83)$.

Minimum temperature trends. The lowest minimum temperature recorded was $20.7^{\circ} \mathrm{C}$ in the derived savannah and $21.2{ }^{\circ} \mathrm{C}$ in the rainforest in 1989 and 1994, respectively (Figs. $2 \mathrm{c}$ and $3 \mathrm{c}$ ). However, the highest minimum temperature observed was $22.0{ }^{\circ} \mathrm{C}$ in 2014 for the derived savannah and $23.2^{\circ} \mathrm{C}$ in 1998 for the rainforest. Increasing trends were observed for the minimum temperature values over the derived savannah $(Z=2.90, P<0.01)$ and rainforest agroecologies $(Z=2.46$, $\mathrm{P}<0.05)$.

Crop yields in Oyo state (1990 - 2016). The data on the total yields (metric tonnes per 1000 ha) of some of the major crops cultivated in Oyo state from 1990- 2016 are presented in Figure 4. Using time as a variable, the coefficient of determinants $\left(\mathrm{R}^{2}=0.10207\right)$ shows a $10.2 \%$ positive variation in the yield of cassava; while $\mathrm{R}^{2}=0.0042$ indicates $0.4 \%$ variation for yam yield. The yield of maize coefficient $\left(R^{2}=0.0301\right)$ shows $3 \%$ variation, and the coefficient for $\mathrm{R}^{2}=0.0049$ indicates $0.49 \%$ variation in cowpea yields over the timeframe. Furthermore, a coefficient of $\mathrm{R}^{2}=$ 0.005 reveals a $0.5 \%$ variation in yield values for okra over 27 years. Likewise, for tree crops, a variation in cashew yields is explained by a coefficient of $R^{2}=0.934$, which shows a high percentage $(93.4 \%)$, and a coefficient of $\mathrm{R}^{2}=0.8998$ for cocoa signifies a variation in the yield of approximately $90 \%$ from 1990 2016.

\section{Weather variability within derived savannah agroecology on crop yields}

Roots and tubers. The coefficients reveal that a percentage rise in rainfall reduces cassava yield by $0.037 \%$ in the derived savannah agroecology, while a percent increase in maximum temperature can improve cassava yield by $18.4 \%$. Rainfall $(\mathrm{P}<0.05)$ had a negative but significant influence on the yield of yam: a percentage rise in the amount of rainfall reduced the yam yield by $0.04 \%$ (Table 2 ). By comparing historical weather data and crop yield data (Figs. 5a and 5d), the results signify that the amount of rainfall received by yam and cassava in the derived savannah agroecology was adequate. The spatial scenarios of the effects of rainfall variability on cassava and yam yields are presented in Figures 5a and 5d, respectively.

Cereals, legumes and vegetables. In the derived savannah, a percentage increase in the maximum temperature reduced the maize yield by $6.8 \%$ (Fig. $6 \mathrm{c}$ ). For sorghum $(\mathrm{P}<0.01)$, a percentage increase in maximum temperature reduced the yield by $16.4 \%$. A percentage increase in the minimum temperature $(\mathrm{P}<0.05)$ and rainfall $(\mathrm{P}<0.01)$ reduced the yields of cowpea (Figs. 7a and 5b), and soybean by 20.9 and $0.013 \%$, respectively (Table 2 ). Conversely, a percentage increase in maximum temperature $(\mathrm{P}<0.01)$ increased the tomato yield by $72.1 \%$ and pepper yield $(\mathrm{P}<0.01)$ by 100\% (Fig. 6e and d).

Tree crops. In this study, the minimum temperature $(\mathrm{P}<0.01)$ was found to significantly influence the cashew yield. A percentage rise in the minimum temperature increases the yield by $55.4 \%$ (Fig. 7d).

Weather variability within rainforest agroecology on crop yields. Table 3 reveals the results of stepwise regression indicating the effects of weather variability on crop yields 
Implications of weather variability across agroecologies

(a)
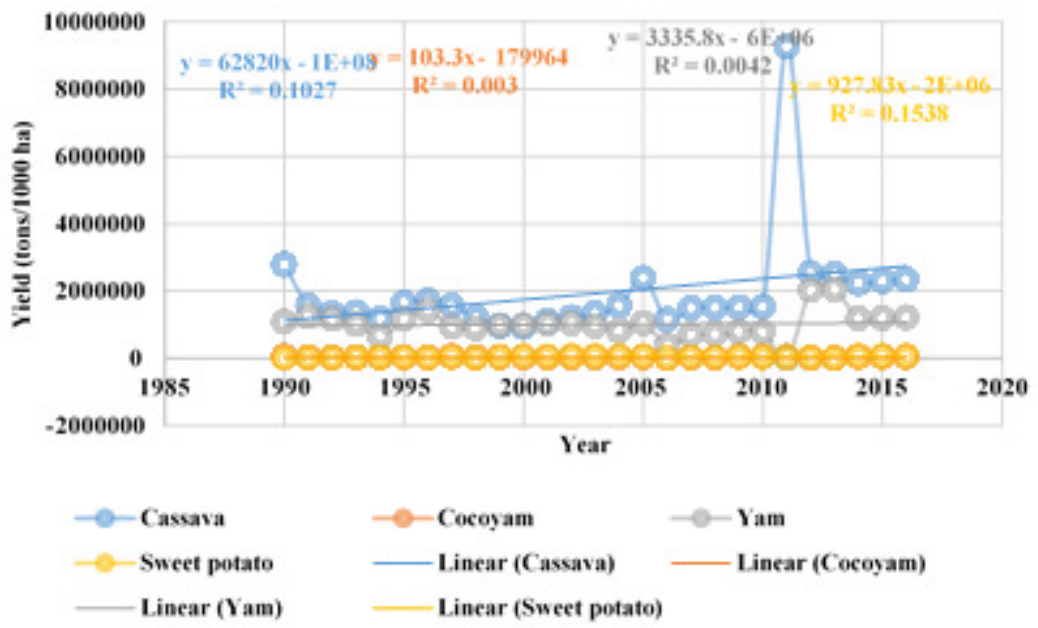

(b) 200000

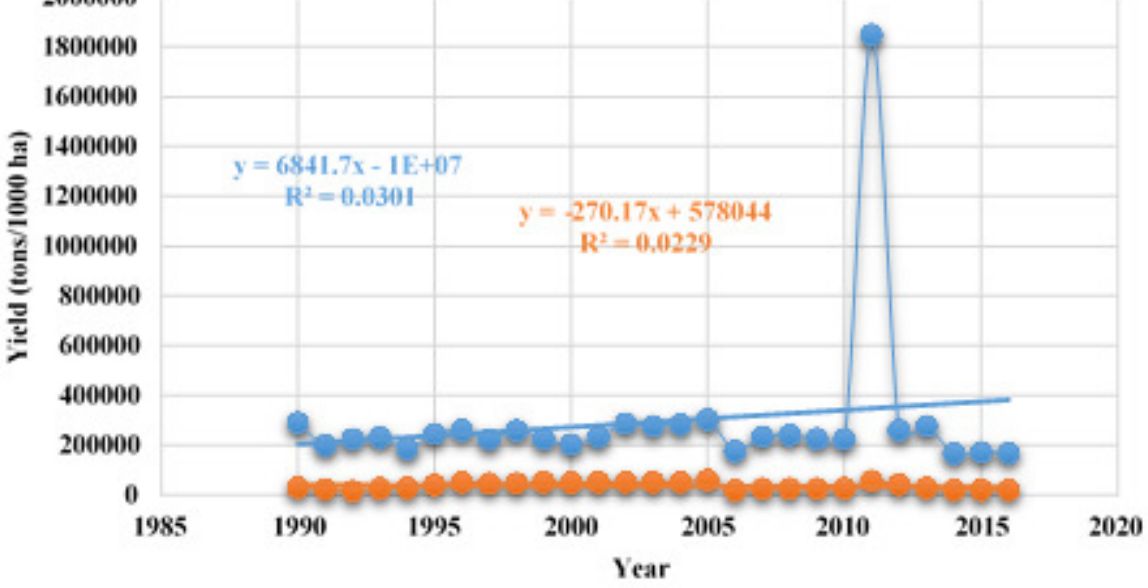

$\multimap-$ Maize $\rightarrow$ Sorghum - Linear (Maize) - Linear (Sorghum)

(c)

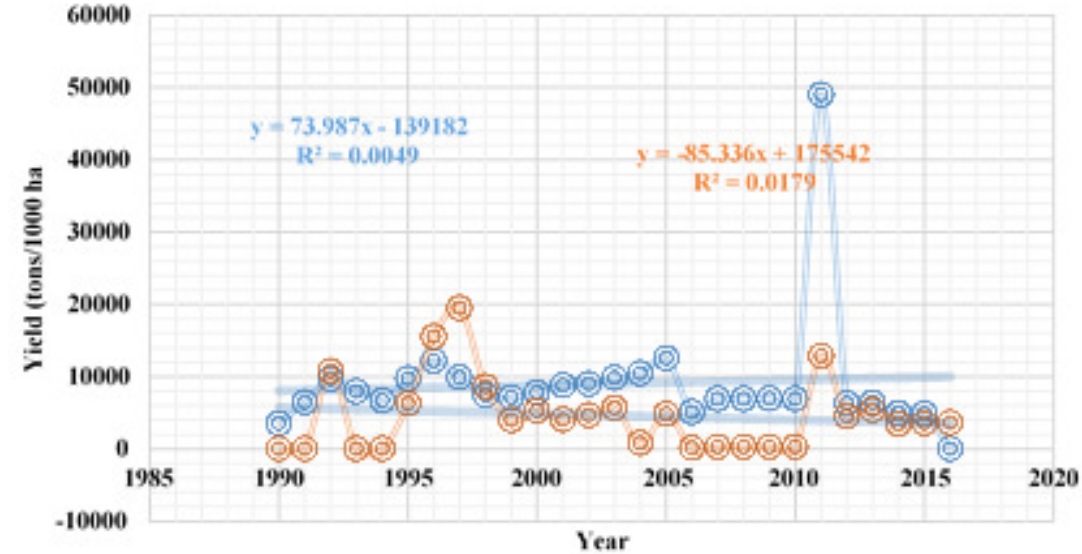

- Cowpea $=$ Soybean Linear (Cowpea) Linear (Soybean) 
(d)

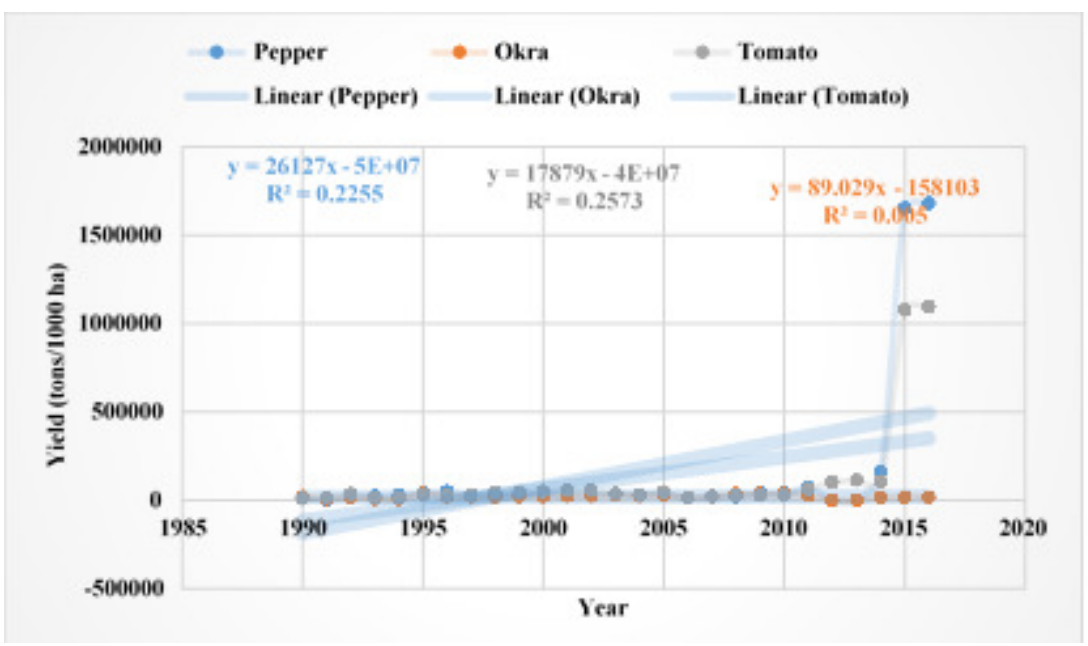

(e)

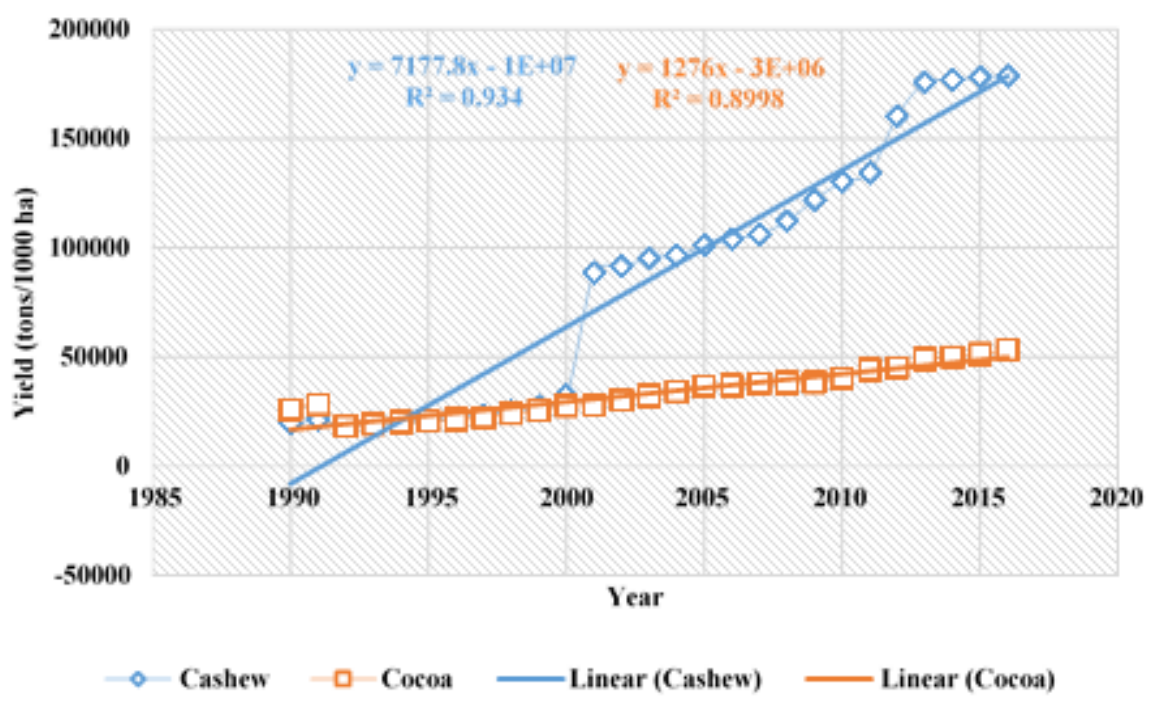

Figure 4. Yield of some major crops cultivated in Oyo state: (a) root and tuber (b) cereal (c) legume (d) vegetable (e) tree crop.

in the rainforest agroecology of Oyo state over a period of 27 years.

Roots and tubers. The results reveal that rainfall had no significant effect on cassava yield in rainforest agroecology. However, a positive relationship between rainfall and cassava tended to occur in the last step (Step 4 ) of the backward elimination process. The coefficients of rainfall $(\mathrm{P}<0.05)$ and maximum temperature $(\mathrm{P}<0.10)$ indicated significant relationships with cocoyam yield in the first step (1) of the regression. A percentage increase in rainfall increased cocoyam yield by $0.032 \%$. However, a percentage increase in the maximum temperature reduced the yield of cocoyam by $28.2 \%$. Rainfall was found to significantly influence $(\mathrm{P}<0.10)$ sweet potato yield with a percentage increase of $0.067 \%$ from 1990 to 2016. 
TABLE 2. Effects of weather variability in the derived savannah agroecology on crop yields in Southwestern Nigeria

\begin{tabular}{|c|c|c|c|c|c|c|}
\hline \multicolumn{3}{|c|}{ Agroecology } & \multicolumn{4}{|c|}{ Derived savannah } \\
\hline Variable & Step & Parameter Est & $\mathrm{SE}$ & Type II SS & $\mathrm{F}$ & $\mathrm{P}$ \\
\hline \multicolumn{7}{|c|}{ Root and tuber crops } \\
\hline Cassava & & & & & & \\
\hline Rainfall & 3 & -0.00037 & 0.000213 & 0.1063 & 3.01 & $0.09 *$ \\
\hline Max temp & 3 & 0.18413 & 0.10086 & 0.11761 & 3.33 & $0.08 *$ \\
\hline $\begin{array}{l}\text { Yam } \\
\text { Rainfall }\end{array}$ & 5 & -0.0004 & 0.000149 & 0.12546 & 7.22 & $0.01 * * *$ \\
\hline \multicolumn{7}{|c|}{ Cereal, legume and vegetable crops } \\
\hline $\begin{array}{l}\text { Maize } \\
\text { Max temp }\end{array}$ & 5 & -0.06763 & 0.07344 & 0.03064 & 0.85 & 0.366 \\
\hline $\begin{array}{l}\text { Sorghum } \\
\text { Max temp }\end{array}$ & 4 & “0.16376 & 0.09285 & 0.09323 & 3.11 & $0.09 *$ \\
\hline $\begin{array}{l}\text { Cowpea } \\
\text { Min temp }\end{array}$ & 5 & -0.20914 & 0.1134 & 0.13054 & 3.4 & $0.08 *$ \\
\hline $\begin{array}{l}\text { Soybean } \\
\text { Rainfall }\end{array}$ & 5 & -0.00134 & 0.000749 & 1.193 & 3.18 & $0.09 *$ \\
\hline $\begin{array}{l}\text { Pepper } \\
\text { Max temp }\end{array}$ & 5 & 1.01383 & 0.15646 & 5.82088 & 41.99 & $0.000 * * *$ \\
\hline $\begin{array}{l}\text { Tomato } \\
\text { Max temp }\end{array}$ & 5 & 0.72104 & 0.1255 & 3.48342 & 33.01 & $0.000 * * *$ \\
\hline Tree crop & & & & & & \\
\hline $\begin{array}{l}\text { Cashew } \\
\text { Min temp }\end{array}$ & 5 & 0.55444 & 0.16369 & 1.06519 & 11.47 & $0.002 * * *$ \\
\hline
\end{tabular}

$* * * \mathrm{P}<0.01, * * \mathrm{P}<0.05, * \mathrm{P}<0.10$

Cereals, legumes and vegetables. A percentage increase in rainfall increased maize yield by $0.021 \%$ in the rainforest agroecology (Table 3). Similarly, a percentage increase in rainfall increased cowpea yield by $0.029 \%$ (Fig. $5 b)$. Furthermore, a percentage increase in the minimum temperature $(\mathrm{P}<0.10)$ will increase the pepper yield by $46.2 \%$ (Fig. 7b). Moreover, a percentage increase in the amount of rainfall potentially increases the okra yield by $0.024 \%$. Minimum temperature was found to significantly influence tomato yield $(\mathrm{P}<0.05)$, with a percentage increase of $47.4 \%$ over the 27-year timeframe (Fig. 7c).

Tree crops. The maximum temperature $(\mathrm{P}<0.01)$ significantly influenced the yield of cocoa in the rainforest agroecology, and a percentage increase in the maximum temperature reduced the cocoa yield by $37.8 \%$ (Fig. 6b). 

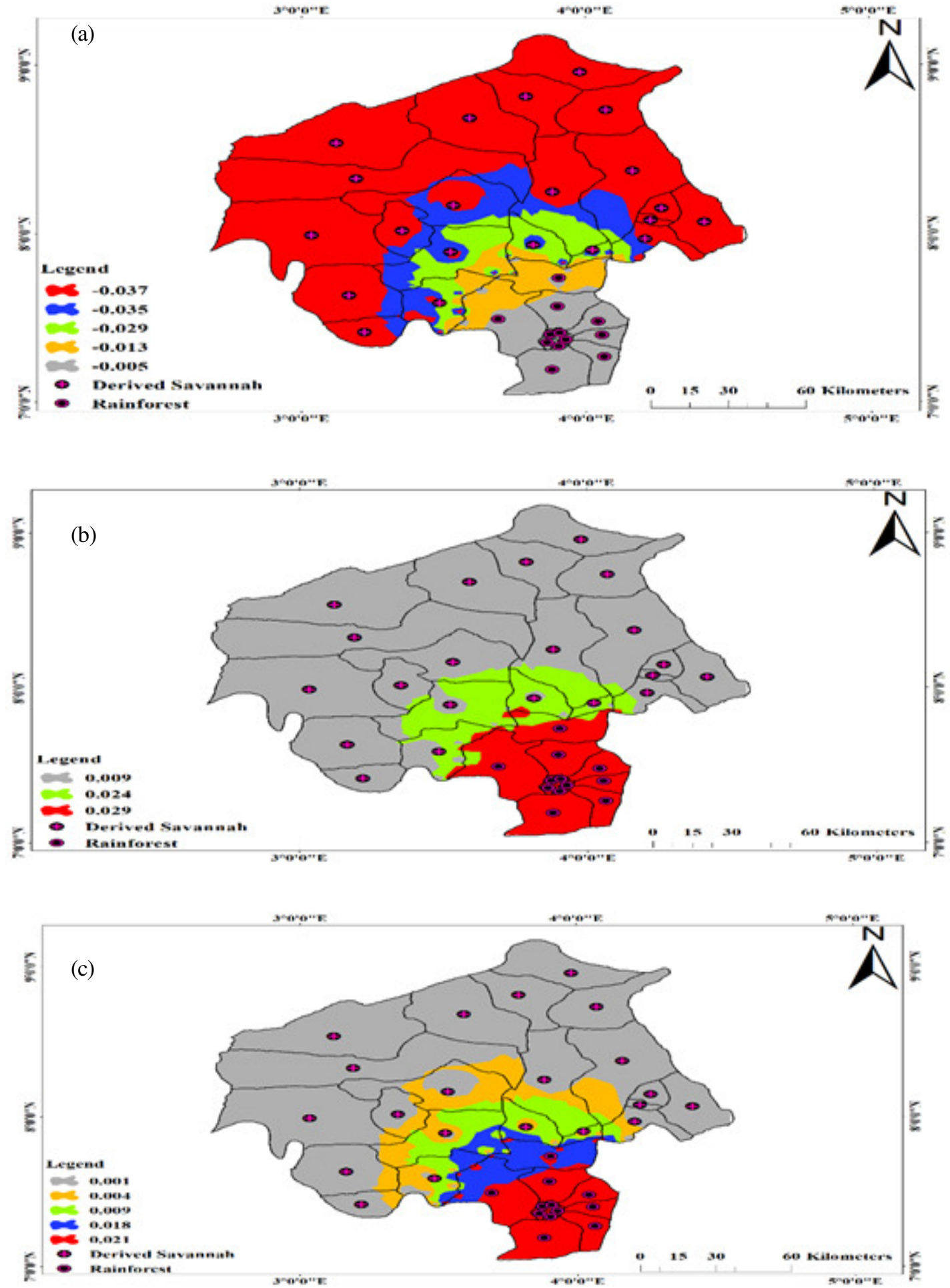


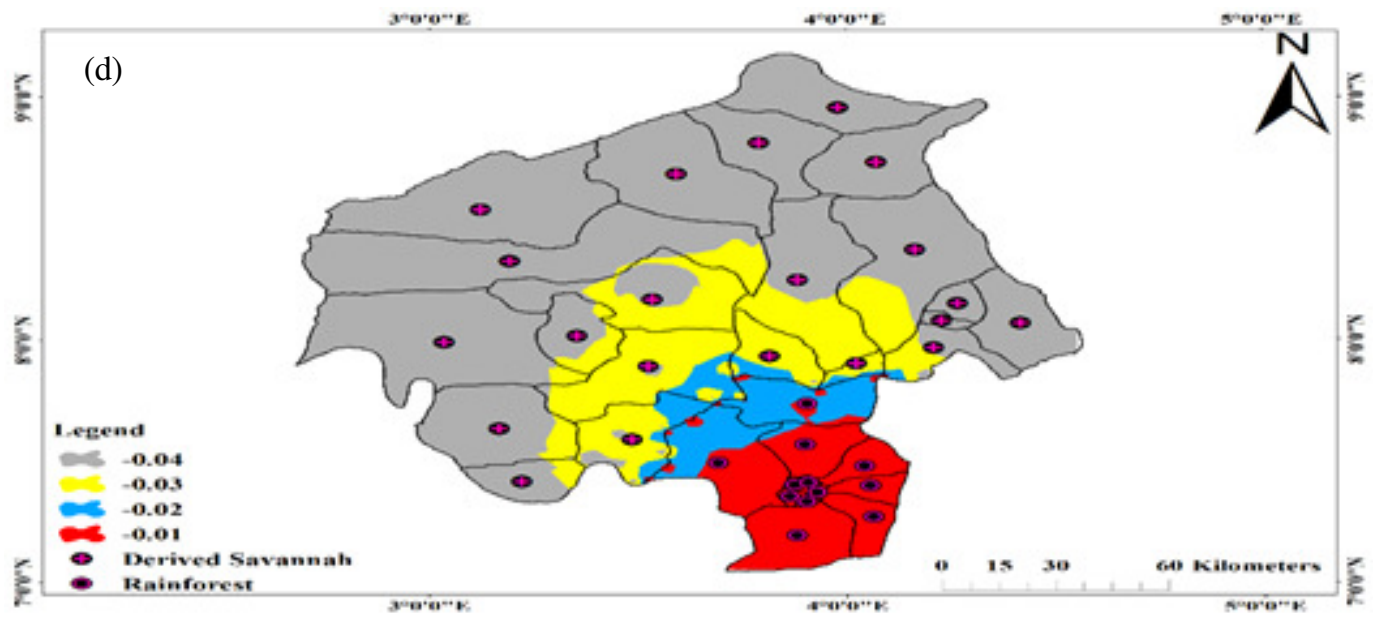

Figure 5. Spatial analysis showing effects of variations in rainfall on crop yields: (a) cassava (b) cowpea (c) maize (d) yam. Values in percentage.

\section{DISCUSSION}

A key finding from our study is that the scale of variability in temperature is more poignant than that of rainfall in the agroecologies of Oyo state (Figs. 2a-c and 3a-c). No significant trends in the rainfall distribution were observed for the derived savannah and rainforest agroecologies (Figs. 2a and 3a). We discovered increasing trends for the maximum $(Z=3.88$, $\mathrm{P}<0.001)$ and minimum $(\mathrm{Z}=2.90, \mathrm{P}<0.01)$ temperatures in the derived savannah (Figs. $2 \mathrm{~b}-\mathrm{c})$, and minimum temperature $(\mathrm{Z}=2.46$, $\mathrm{P}<0.05$ ) in the rainforest (Fig. 3c). To this end, the results posit that the scale of temperature variation in the derived savannah is more severe than that in the rainforest agroecology. In the derived savannah, short season crops coupled with climate adaptation techniques such as the use of drought and heat-tolerant crops, afforestation, water conservation techniques and planting season dynamics will be most desired for grappling with the increasing temperature trend. Likewise, agricultural stakeholders in the rainforest agroecology need to be encouraged to adopt the widespread use of water conservation and drought management techniques to curb imminent eventualities of increasing temperature in the agroecology.
Additionally, temperature increases in the agroecologies of Oyo state can impede soils from being productive through increased levels of nitrate leaching and the lack of nitrates in the soil because of the heightened turnover rate of soil organic matter, which is a building block for soil fertility, sustainability and productivity (Olesen and Bindi, 2002). Continuous temperature increases, coupled with limited rainfall, produce drier soil conditions through the high evaporation rates, resulting in the risk of wind erosion that undermines the topsoil and increases the possibility of salinity (Yeo, 1998). This resultant condition can jeopardise the production of cereal, legume and vegetable crops in the agroecologies of Oyo state due to their rooting mainly anchored in the topsoil layer.

Consequently, increasing temperatures across agroecologies could intensify respiration processes, accelerate development and hasten maturation without the plant completing proper growth processes, thereby reducing crop yields (Rötter and Van de Geijn, 1999; Olesen and Bindi, 2002). Owing to warmer environments in which pests and diseases would thrive, increases in temperature, as observed from our results, intensify pest and disease outbreaks in the agricultural production cycle (Rosenzweig et 

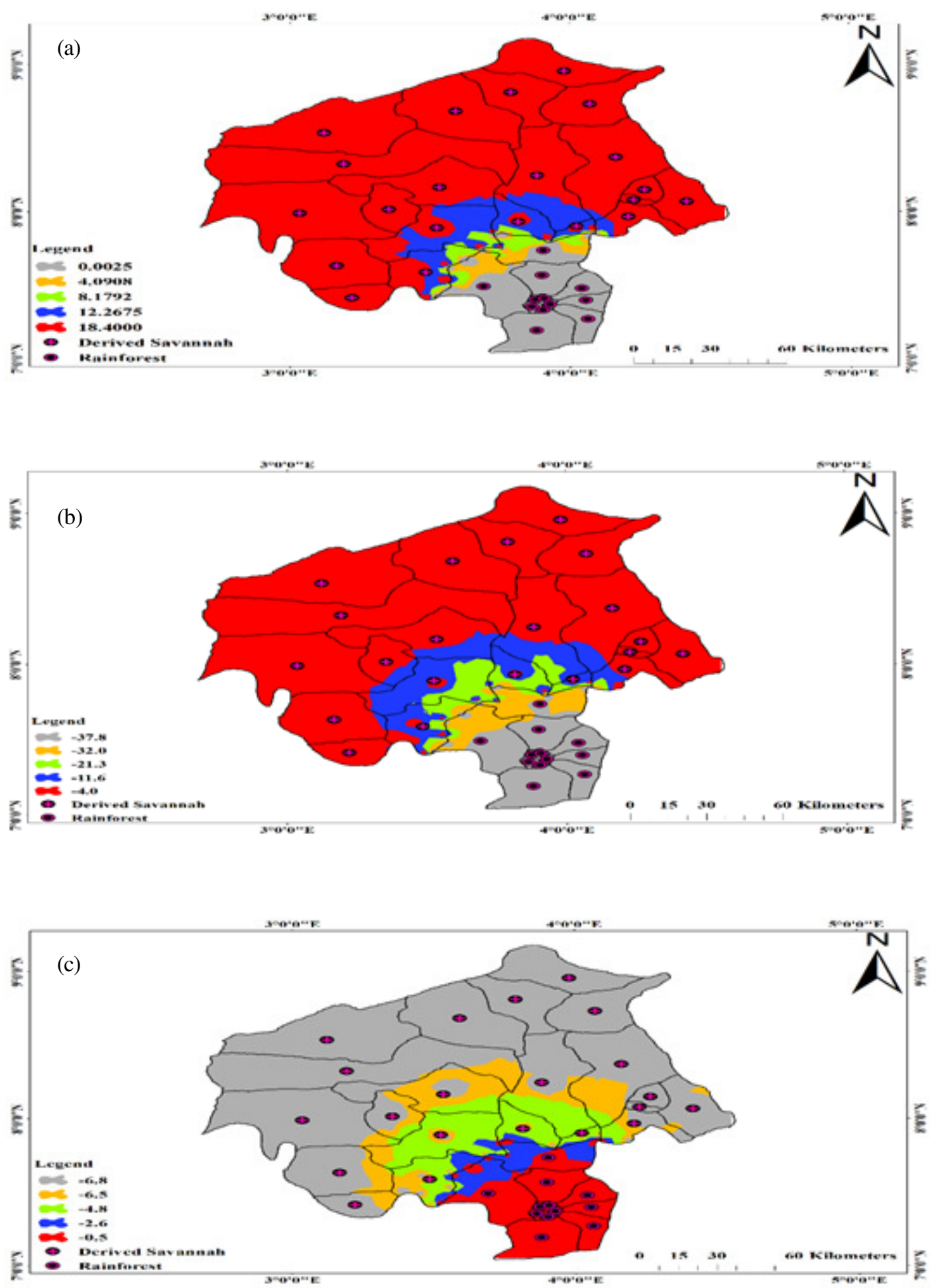


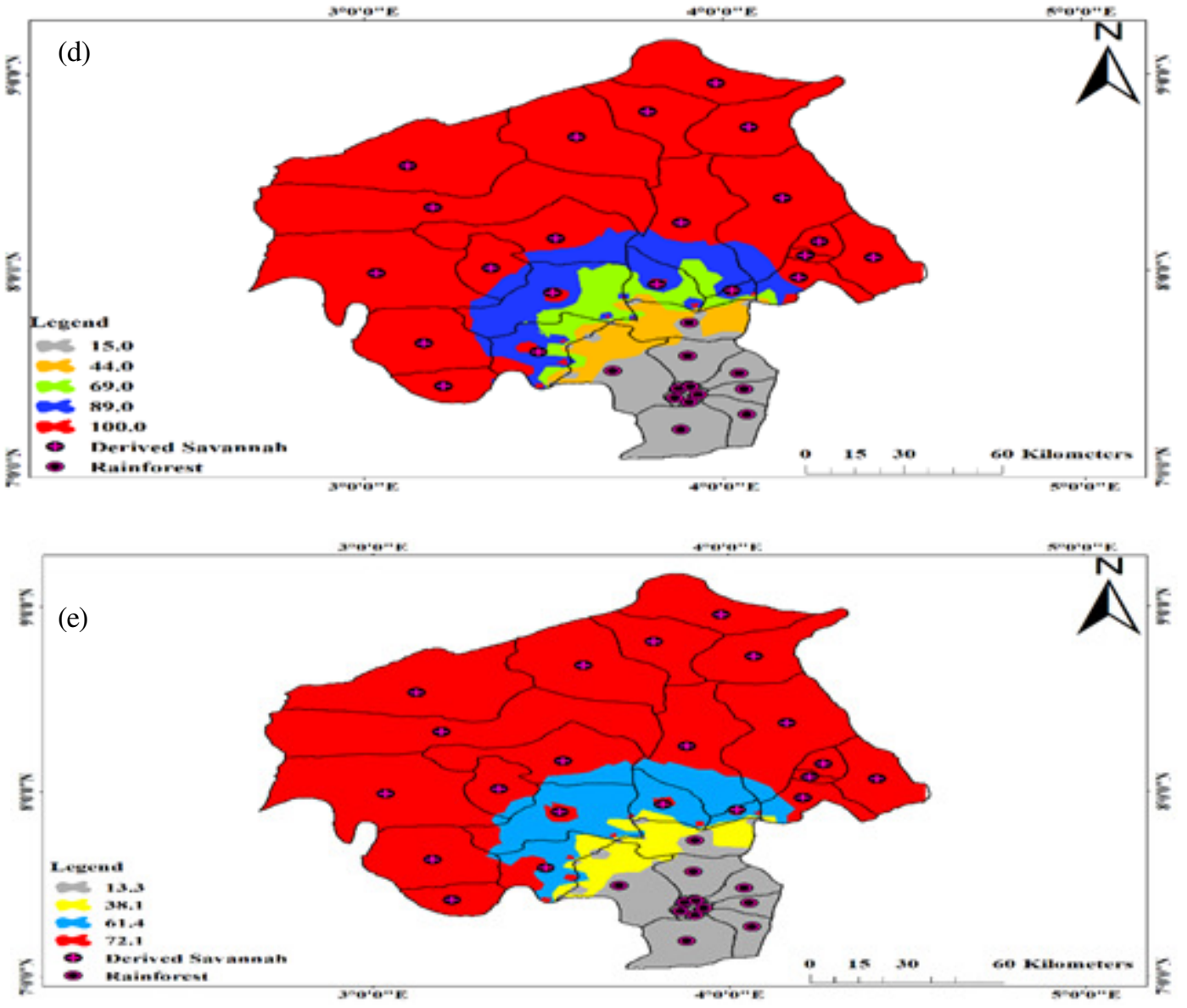

Figure 6. Spatial analysis showing the effects of variations in maximum temperature on crop yields: (a) cassava (b) cocoa (c) maize (d) pepper (e) tomato. Values in percentage.

al., 2001). This would also affect growth and development of crops and animals, as an unabated increase in temperature would obstruct plant and animal survival.

Large scale variations were observed for the yields of cashew (93.4\%) and cocoa (90.0\%) (Fig. 4e). Nonetheless, minimal variations were observed for tomato $(23.7 \%)$, pepper $(22.6 \%)$, sweet potato $(15.4 \%)$ and cassava $(10.3 \%)$. Near negligible deviations were observed for maize $(3.0 \%)$, sorghum $(2.3 \%)$, soybean $(1.8 \%)$, okra $(0.5 \%)$, cowpea $(0.49 \%)$, yam $(0.4 \%)$, and cocoyam $(0.3 \%)$ yields. Evidently, cassava (Fig. 4a) and maize (Fig. 4b) are the most cultivated crops in Oyo state (Alo et al., 2017; Oyegbami, 2018) in terms of yield; hence, they are the major food and nutrition security crops (Fawole and Oladele, 2007). Inferentially, our results posit that cassava and maize are the most impacted by weather variability across both agroecologies.

Rainfall over the derived savannah during the study period revealed a negative correlation $(-3.7 \%)$ with cassava yield; while warmer temperatures appeared to be advantageous $(+18 \%)$ for cassava yield (Table 2$)$. Therefore, a near steady trend in cassava yields could be feasible where rainfall decreases and temperature increases over the derived savannah. This submission is valid because cassava can grow at temperatures above $29^{\circ} \mathrm{C}$ 

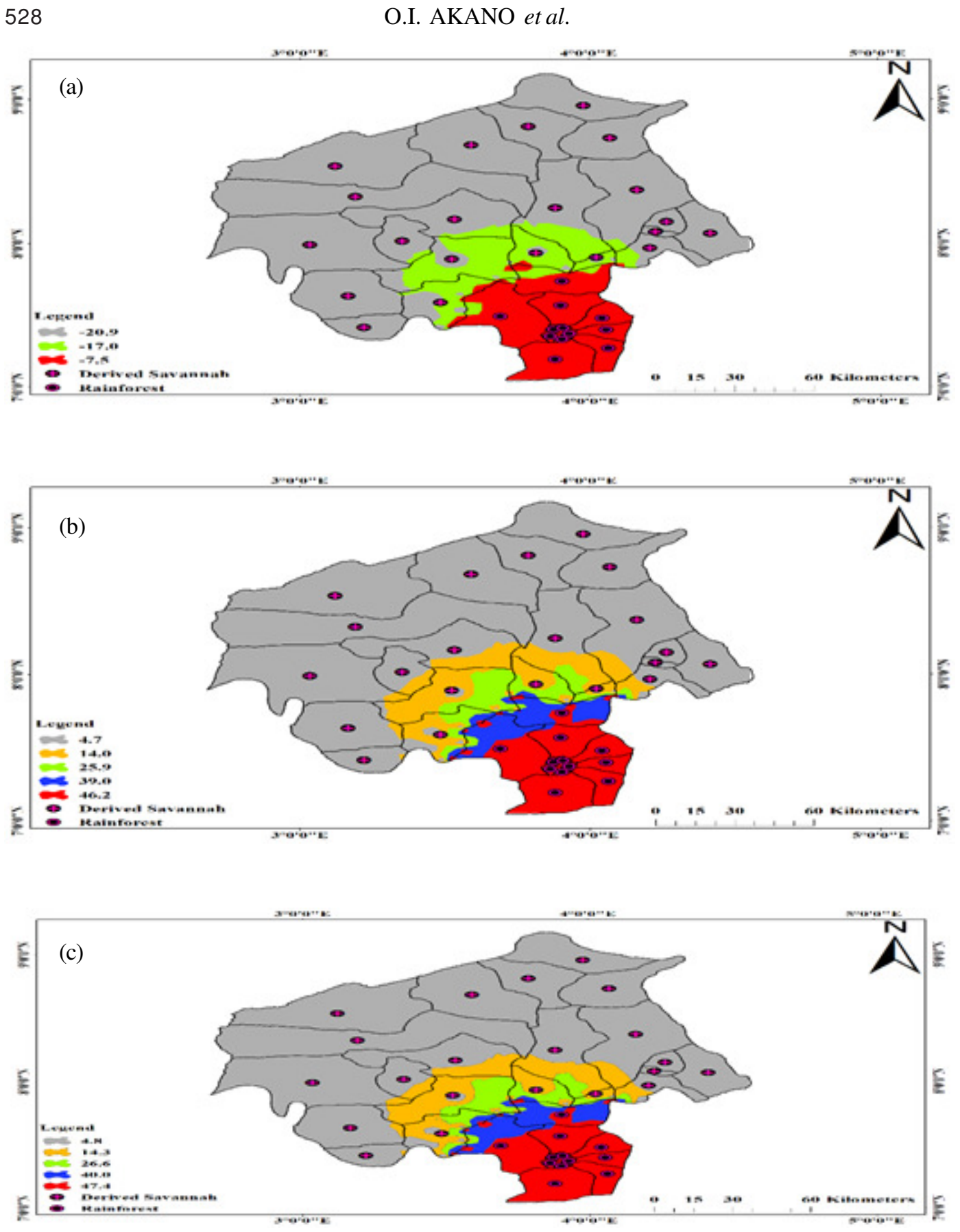


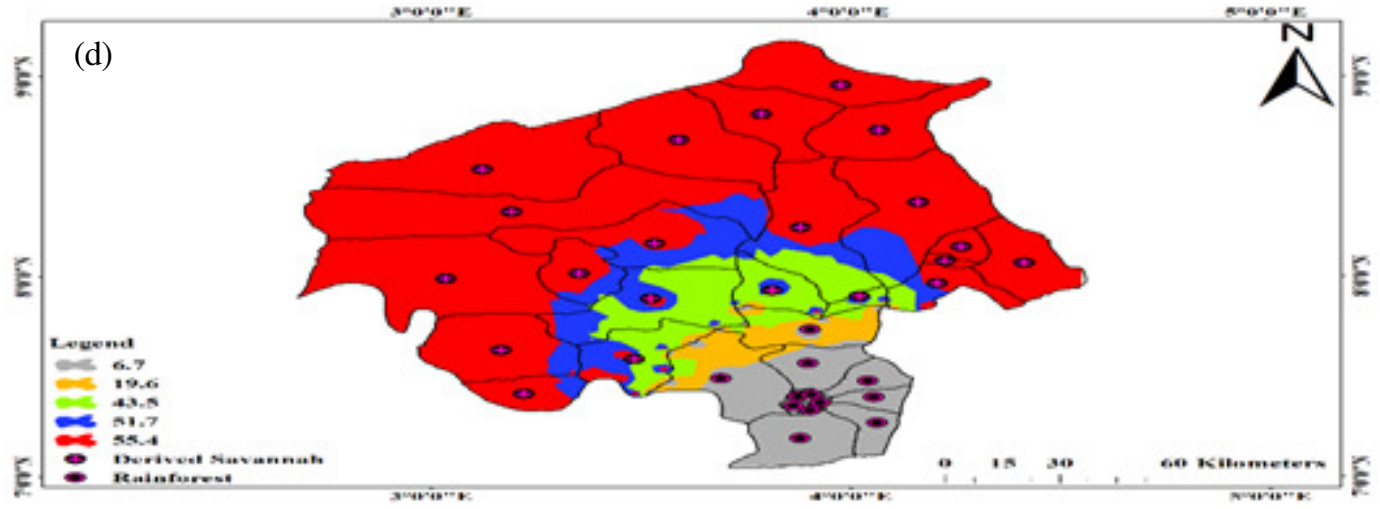

Figure 7. Spatial analysis showing the effects of variations in minimum temperature on crop yields: (a) cowpea (b) pepper (c) tomato (d) cashew. Values in percentage.

and above $500 \mathrm{~mm}$ of rainfall per annum (PCARRD/USDA, 1986).

Cassava will be an important contributor to food availability and stability, and improve rural livelihoods in the weather variability phase across the agroecologies of Oyo state and the Southwest region. Cassava serves as a source of traditional food stuffs and common cuisines in the study area, including garri, fufu, edible starch, elubo-lafun, abasha and tapioca. The possibility of producing cassava under adverse temperature conditions in Oyo state (Adewuyi et al., 2015) would also assist in ensuring feed supplies to household livestock, as cassava peels and pellets are found to be major constituents in livestock and poultry feed. This is attainable by adopting drought and diseasetolerant, high-yielding and early-maturing varieties of cassava across both agroecologies of the state.

Similarly, increasing maximum temperature exhibited a negative relationship with maize yield $(-6.8 \%)$ in the derived savannah. In the rainforest, higher rainfall amounts will support $(+2 \%)$ better maize yield (Table 2$)$. Basically, cropping maize in the derived savannah under warming conditions jeopardises the attainment of desired yields. Interventions such as the use of drought tolerant, disease resistant, early maturing and high yielding maize varieties are plausible. Farmers will need to explore the dynamics of changing planting dates to wetter periods of the year. On the other hand, the results suggest that cultivating maize for maximum yields in the rainforest will be most advantageous during peak rainy season. In the tropics, maize cultivation requires more than $610 \mathrm{~mm}$ of water per crop, 6-8 mm per day during the silking stage, a minimum temperature of $18-24^{\circ} \mathrm{C}$ and a maximum temperature of $32-35^{\circ} \mathrm{C}$ during the growth phase (PCARRD/USDA, 1986). Therefore, farmers will need to be furnished with accurate agro-weather information to achieve sustainable maize production in the rainforest agroecology.

As a vital food and nutrition security crop, maize is important in the diet of both humans and livestock in Oyo state and Southwest Nigeria (Fawole and Oladele, 2007). It is used in the production of common food items and family dishes such as pap, tuwo, egbo, masa, and abari. It is also a major constituent of poultry feed. Crop failures and poor yields, occasioned by a reduction in the rainfall received; coupled with increasing temperature values (Ajetomobi et al., 2015; Mkonda and He, 2018) as obtained from our results, will jeopardise the attainment of food security, especially among rural dwellers and maizedependent livelihoods in the agroecologies of Oyo state. This situation will arise as a result of reduced access to, minimal utilisation and availability of maize. Subsequently, the need 
TABLE 3. Effects of weather variability in the rainforest agroecology on crop yields in Southwestern Nigeria

\begin{tabular}{|c|c|c|c|c|c|c|}
\hline \multicolumn{3}{|c|}{ Agroecology } & \multicolumn{3}{|c|}{ Rainforest } & \multirow[b]{2}{*}{$\mathrm{P}$} \\
\hline Variable & Step & Parameter Est & $\mathrm{SE}$ & Type II SS & $\mathrm{F}$ & \\
\hline \multicolumn{7}{|c|}{ Root and tuber crops } \\
\hline $\begin{array}{l}\text { Cassava } \\
\text { Rainfall }\end{array}$ & 4 & 0.000255 & 0.000163 & 0.09173 & 2.44 & 0.13 \\
\hline $\begin{array}{l}\text { Cocoyam } \\
\text { Rainfall } \\
\text { Max temp }\end{array}$ & $\begin{array}{l}1 \\
1\end{array}$ & $\begin{array}{c}0.000319 \\
-0.28234\end{array}$ & $\begin{array}{l}0.000148 \\
0.16331\end{array}$ & $\begin{array}{l}0.12777 \\
0.08174\end{array}$ & $\begin{array}{l}4.67 \\
2.99\end{array}$ & $\begin{array}{l}0.04 * * \\
0.09 *\end{array}$ \\
\hline $\begin{array}{l}\text { Sweet pota } \\
\text { Rainfall }\end{array}$ & 3 & 0.000616 & 0.000344 & 0.5126 & 3.19 & $0.09 *$ \\
\hline \multicolumn{7}{|c|}{ Cereal, legume and vegetable crops } \\
\hline $\begin{array}{l}\text { Maize } \\
\text { Rainfall }\end{array}$ & 4 & 0.000207 & 0.000158 & 0.06014 & 1.72 & 0.20 \\
\hline $\begin{array}{l}\text { Cowpea } \\
\text { Rainfall }\end{array}$ & 4 & 0.000229 & 0.00017 & 0.07356 & 1.81 & 0.19 \\
\hline $\begin{array}{l}\text { Pepper } \\
\text { Min temp }\end{array}$ & 4 & 0.46211 & 0.2501 & 1.16445 & 3.41 & $0.08 *$ \\
\hline $\begin{array}{l}\text { Okra } \\
\text { Rainfall }\end{array}$ & 4 & 0.000241 & 0.00016 & 0.08198 & 2.27 & 0.15 \\
\hline $\begin{array}{l}\text { Tomato } \\
\text { Min temp }\end{array}$ & 4 & 0.47382 & 0.1784 & 1.34711 & 7.05 & $0.01 * * *$ \\
\hline Tree crops & & & & & & \\
\hline $\begin{array}{l}\text { Cocoa } \\
\text { Max temp }\end{array}$ & 3 & -0.37771 & 0.10921 & 0.16469 & 11.96 & $0.002 * * *$ \\
\hline
\end{tabular}

$* * * \mathrm{P}<0.01, * * \mathrm{P}<0.05, * \mathrm{P}<0.10$

for supplemental irrigation to maize-cropped areas in the derived savannah agroecology would be imperative for the sustainable production of maize.

Increasing rainfall and temperature over the rainforest appears to support better yields for cowpea, pepper, tomato and okra (Table 3). A reduction in the yield of cowpea and soybean (Table 2), as occasioned by dwindling rainfall and surging minimum temperature in the derived savannah (Figs. 2a, b and c), would foster malnourishment and nutrition insecurity in the agroecology. However, an increase in maximum temperature appears to be advantageous for pepper and tomato yields (Table 2). Households, especially in remote areas, derive protein and balance their diets from leguminous crops (Maphosa and Jideani, 2017). They consume legumes that are readily available to them, where a range of animal sources of protein are occasionally inaccessible or costly (Adekunmi et al., 2017). 
Moreover, legumes and vegetables are established crops whose timeframe to mature largely depends on day length and temperature. Where rainfall decreases and temperature increases (Figs. 2a, b, c and 3c), a reduced growing period invariably reduces their yields (Olesen and Bindi, 2002) if interventions through improved management techniques are not employed (Tubiello et al., 2000). Additionally, intercropping legumes with other crop classes will aid nitrogen fixation in the soil, fit as substitute crops in rotations, enhance nutrient cycling and reduce total crop losses (Stagnari et al., 2017). Therefore, the widespread adoption of intercropping legumes and vegetables with other classes of crops, especially in the derived savannah agroecology is vital for cushioning the effects of weather variability on legume yields and fostering nutrition security.

Agroforestry arrangements where cashews are vital tree crops is probable under increasing minimum temperatures in the derived savannah agroecology (Table 2, Fig. 6b). This resonates with proliferating cashew plantations being a plausible climate-smart agricultural technique well suited to the derived savannah agroecology of Oyo state. An increase in cashew yield under possible temperature increases will improve rural access to, availability and utilisation of vitamins and minerals supplied by cashew fruit, likewise, protein and oils from the nut. On the other hand, cocoa-dependent livelihoods and farmers in the rainforest will be severely impacted by the reductions in cocoa yield necessitated by increasing temperatures over the agroecology (Table 3 ). The use of early maturing, high yielding, water-use efficient, and drought resistant cocoa varieties will greatly assist with improving cocoa yields in the rainforest agroecology of Oyo state.

\section{CONCLUSION}

We have discovered that further increases in yearly rainfall above $2000 \mathrm{~mm}$ in the derived savannah will significantly diminish cassava and yam yields by more than 3.7 and $4 \%$, respectively. The increase in maximum and minimum temperatures will also potentially reduce sorghum and cowpea yields. These trends of increases above $2^{\circ} \mathrm{C}$ for minimum and maximum temperature over the 27 -year time frame may be highly detrimental to the livelihood of smallholder farmers and rural dwellers, their nutrition and food security crops, and the entirety of the derived savannah. In the rainforest agroecology, an increase in maximum temperatures drastically reduced the yields of cocoyam and cocoa. Farmers in the agroecology with agro-forestry-based livelihoods are at a disadvantage in terms of crop yields due to weather variability.

The information generated from a concurrent exercise on examining the effects of weather variability on crop yields would avail farmers the opportunity to put up effective adaptation measures to combat the effects of weather variability on their farming operations. This will promote enhanced agricultural livelihoods, food and nutrition security in Oyo state and Southwest Nigeria. Subsequently, as temperatures rise, rainfall patterns change and rainfall variability increases; farmers will need to grow different crops, plant at different times, use different inputs, raise different animals and be equipped for unending changes.

\section{ACKNOWLEDGEMENT}

This study is drawn from a part of the $\mathrm{PhD}$ research of the corresponding author. The corresponding author appreciates North-West University for postgraduate bursary support. We acknowledge the Oyo State Agricultural Development Programme (OYSADEP), Oyo State Ministry of Agriculture, Natural Resources and Rural Development, Nigerian Meteorological Agency (NiMET) and International Institute of Tropical Agriculture (IITA) for the secondary data. 


\section{REFERENCES}

Abu, J., Okwori, J., Ajegi, S.O. and Ochinyabo, S. 2015. An empirical investigation of malthusian population theory in Nigeria. Journal of Emerging Trends in Economics and Management Sciences 6:367-375.

Adejuwon, J.O. 2006. Food crop production in Nigeria. II. Potential effects of climate change. Climate Research 32:229-245.

Adekunmi, A., Ayinde, J. and Ajala, A. 2017. An assessment of animal protein consumption patterns among rural dwellers in Osun state, Nigeria. Ife Journal of Agriculture 29:84-94.

Adewuyi, S., Folorunso, B., Okojie, L. and Akerele, D., 2015. Effect of climate change on food crop production and vulnerability assessment in Oyo State. Journal of Economics and International Finance 7:1824.

AGRA, 2014. Climate change and smallholder agriculture in sub-Saharan Africa. Africa agriculture status report. Alliance for a Green Revolution in Africa, Nairobi Kenya. $277 \mathrm{pp}$.

Ajetomobi, J., Ajakaiye, O. and Gbadegesin, A. 2015. The potential impact of climate change on Nigerian agriculture. International Food Policy Research Institute (IFPRI).

Ajetomobi, J.O., Abidun, A. and Hassan, R.M. 2010. Economic impact of climate change on irrigated rice agriculture in Nigeria. No. 308-2016-5082. pp. 1-20.

Alo, A.O., Baines, R., Conway, J. and Cannon, N. 2017. The impacts of climate change on agriculture in developing countries: A case study of Oyo State, Nigeria. International Journal of Climate Change: Impacts and Responses 9(2):1-21.

Ayanlade, A., Radeny, M. and Morton, J.F. 2017. Comparing smallholder farmers' perception of climate change with meteorological data: A case study from
Southwestern Nigeria. Weather and Climate Extremes 15:24-33.

Bello, O., Ganiyu, O., Wahab, M., Afolabi, M., Oluleye, F., Mahmud, J., Azeez, M. and Abdulmaliq, S. 2012. Evidence of climate change impacts on agriculture and food security in Nigeria. International Journal of agriculture and Forestry 2:49-55.

Cammell, M. and Knight, J. 1992. Effects of climatic change on the population dynamics of crop pests. Advances in Ecological Research. Elsevier. pp. 117-162.

CBN, 2006. Central bank of Nigeria. Statistical Bulletin. CBN, Abuja.

CBN, 2011. The Statistical Bulletin of Central Bank of Nigeria. CBN, Abuja.

Challinor, A.J., Watson, J., Lobell, D.B., Howden, S., Smith, D. and Chhetri, N. 2014. A meta-analysis of crop yield under climate change and adaptation. Nature Climate Change 4:287.

Em-dat, 2013. The OFDA/CRED International Disaster Database. 2001. Belgium, Université Catholique de Louvain. 37pp.

Fabusoro, E., Sodiya, C., Fasona, M. and Oyedepo, J. 2014. Vulnerability of settled Fulani agro-pastoralists' livelihoods to climate change and emerging innovations for adaptation and land accessibility in Southwest Nigeria, 2013-02. Washington, DC: International START Secretariat.

FAO, 2006. Demands for products of irrigated agriculture in sub-Sahara Africa. Food and Agriculture Organization of the United Nations, Rome, Italy.

FAO, 2015. Coping with climate change: The roles of genetic resources for food and agriculture. FAO.

FAO, 2019. Nigeria at a glance, FAO in Nigeria. FAO. pp. 49-58.

Fawole, O. and Oladele, O. 2007. Sustainable food crop production through multiple cropping patterns among farmers in South Western Nigeria. Journal of Human Ecology 21:245-249.

Fosu-Mensah, B.Y., Vlek, P.L. and MacCarthy, D.S. 2012. Farmers' perception and 
adaptation to climate change: a case study of Sekyedumase district in Ghana. Environment, Development and Sustainability 14:495-505.

Gilbert, R.O. 1987. Statistical methods for environmental pollution monitoring. John Wiley \& Sons.

Houghton, J. 2009. Global warming: the complete briefing. Cambridge university press.

International Fund for Agricultural Development (IFAD), 2011. Proceedings, IFAD (International Fund for Agricultural Development) Conference on New Directions for Smallholder Agriculture, 2425 January, 2011. Rome, Italy.

Ifejika Speranza, C. 2010. Resilient adaptation to climate change in African agriculture. Studies. No 54. 336pp.

Lewis, M. 2007. Stepwise versus Hierarchical Regression: Pros and Cons. Online Submission.

Maphosa, Y. and Jideani, V.A. 2017. The role of legumes in human nutrition, Functional Food-Improve Health through Adequate Food. IntechOpen. 13pp.

Mkonda, M.Y. and He, X. 2018. Climate variability and crop yields synergies in Tanzania's semiarid agroecological zone. Ecosystem Health and Sustainability 4:5972.

Olesen, J.E. and Bindi, M. 2002. Consequences of climate change for European agricultural productivity, land use and policy. European Journal of Agronomy 16:239-262.

Oni, P., Jimoh, S. and Adebisi, L. 2013. Population pattern and phenological behaviours for selected medicinal plants in Nigeria; implications for ex-situ conservation. Journal of Applied Pharmacological Science 3:052-060.

Oyegbami, A. 2018. Location and distance of farmers to agricultural extension service: implication for agricultural development in Oyo State, Nigeria. South African Journal of Agricultural Extension 46:14-23.
PCARRD/USDA, 1986. Environmental adaptation of crops. Philippine Council for Agriculture and Resource Research and Development (PCARRD)/United State Department of Agriculture (USDA), Los Banos, Laguna, Philippines.

Rosenzweig, C., Iglesius, A., Yang, X.-B., Epstein, P.R. and Chivian, E. 2001. Climate change and extreme weather eventsImplications for food production, plant diseases, and pests. Global Change and Human Health 2:90-104.

Rötter, R. and Van de Geijn, S. 1999. Climate change effects on plant growth, crop yield and livestock. Climatic change 43:651-681. Salmi, T. 2002. Detecting trends of annual values of atmospheric pollutants by the Mann-Kendall test and Sen's slope estimates-the Excel template application MAKESENS. Ilmatieteen laitos.

Sangotegbe, N.S., Obayomi, J.O. and Oluwasusi, J.O. 2015. Adaptation to Climate Change Effects Among Rural Women in Savannah and Forest Zones of Oyo State, Nigeria, Handbook of Climate Change Adaptation. pp. 1469-1487.

Shah, M., Fischer, G. and Van Velthuizen, H. 2008. Food security and sustainable agriculture. the challenges of climate change in Sub-Saharan Africa. International Institute for Applied Systems Analysis, Laxenburg.

Sissoko, K., van Keulen, H., Verhagen, J., Tekken, V. and Battaglini, A. 2011. Agriculture, livelihoods and climate change in the West African Sahel. Regional Environmental Change 11:119-125.

Solomon, S., Manning, M., Marquis, M. and Qin, D. 2007. Climate change 2007-the physical science basis: Working group I contribution to the fourth assessment report of the IPCC. Cambridge university press.

Stagnari, F., Maggio, A., Galieni, A. and Pisante, M. 2017. Multiple benefits of legumes for agriculture sustainability: An overview. Chemical and Biological Technologies in Agriculture 4:2. 
Tubiello, F.N., Donatelli, M., Rosenzweig, C. United Nations. 2017. World population and Stockle, C.O. 2000. Effects of climate change and elevated $\mathrm{CO} 2$ on cropping systems: model predictions at two Italian locations. European Journal of Agronomy prospects.

Yeo, A. 1998. Predicting the interaction between the effects of salinity and climate change on crop plants. Scientia 13:179-189. Horticulturae 78:159-174. 